\title{
SIKAP ETIS KRISTEN TERHADAP PENDERITAAN MENURUT 1PETRUS 4:12-16 DAN RELEVANSINYA BAGI ORANG PERCAYA
}

\author{
Elri Masniari Saragih
}

\section{PENDAHULUAN}

Allah menciptakan manusia menurut gambar dan rupa-Nya (Kej.1:2627). Allah menempatkan manusia pertama di Taman Eden supaya manusia mengusahakan dan dapat menikmati hidup bahagia bersama dengan Allah (Yer. 29:11).

Alkitab berbicara tentang kesenangan dan kebahagiaan jasmani dan rohani, sebagai berkat Allah untuk orang-orang yang dikasihi-Nya, termasuk di dalamnya keturunan, hidup makmur dan kaya, kedudukan terhormat sebagai kepala, bukan ekor. Banyak tokoh Alkitab yang digambarkan sebagai tokoh yang berkuasa, hidup kaya dan hal itu dipahami sebagai sesuatu yang baik, diberkati dan disertai oleh Tuhan, misalnya Abraham, Ishak, Salomo. Dengan demikian, kekayaan bukanlah kutukan, dia dapat dipakai sebagai alat pelayanan. ${ }^{1}$ Tetapi di pihak lain, Alkitab juga berbicara tentang penderitaan yang paling hebat yang dialami oleh Tuhan Yesus sendiri. Dia yang adalah Tuhan telah meninggalkan sorga, lalu 'turun' ke dunia dan mengambil bentuk yang paling rendah (inkarnasi). Ia hidup dalam kemiskinan, Ia ditolak oleh kaum keluarga-Nya, orang sekampung-Nya, bahkan bangsa-Nya sendiri. Hidup-Nya berakhir di kayu salib yang adalah lambang kehinaan, kenistaan dan penderitaan fisik yang luar biasa. ${ }^{2}$

Kristus telah mengalami nasib yang begitu hina, maka tidak mengherankan bila nasib yang sama menimpa para pengikutnya. Dimulai dari Stefanus, para rasul lainnya, seperti Yakobus, Petrus, Paulus pun mengikuti jejak-Nya. Dalam barisan ini, rasul Paulus termasuk yang paling banyak mengalaminya (bd. 2 Kor.11:23-28). Rasul Yohanes disingkirkan ke Pulau

1 B. Kreysen Purba, "Menderita Karena Pilihan: Sebuah Renungan Tentang Imperatif Penderitaan Di Tengah Komunitas Yang Pluralistik", Jurnal TeologiStulos (Bandung: STTB,2010), 25.

2 Ibid,27-28. 
Patmos (Why.1:9). Bahkan menurut tradisi gereja, semua rasul, kecuali Yohanes, mati sebagai martir. ${ }^{3}$

Di Indonesia, dari data-data yang berhasil dikumpulkan, dilaporkan telah ada lebih dari 1.000 gereja yang dirusak, dihancurkan, dibakar oleh orang-orang yang 'Beragama Lain' dari kelompok radikal dan sejumlah orang Kristen dibunuh, dianiaya, dan dipenjarakan. Kekristenan dianggap hal yang asing dan 'membahayakan' ajaran umat 'Beragama Lain'. Anggapan tersebut banyak mendasari sejumlah pengrusakan tempat ibadah dan penganiayaan. Beberapa undang-undang baru yang telah disahkan menempatkan orang-orang Kristen pada situasi yang sulit berkenan dengan aktivitas keagamaannya. Total sampai Januari 2009, 1030 tempat ibadah (gereja) di Indonesia dirusak, ditutup, dibakar! ${ }^{4}$

Berdasarkan data penelitian yang dilakukan Universitas Canberra di Australia, peristiwa pembakaran pada 1967 menjadi pemicu terjadinya rentetan pembakaran gereja. Bahkan, dalam penelitian tersebut disebutkan bahwa sejak Indonesia memasuki Era Reformasi total pembakaran gereja sudah lebih dari 1.000 kasus. $^{5}$ Karena itu tulisan ini berusaha menyajikan dan memaparkan sikap etis orang percaya dalam menghadapi penderitaan.

\section{Pengertian Penderitaan Secara Umum}

Secara umum penderitaan adalah menanggung sesuatu yang tidak menyenangkan. Kata "penderitaan" berasal dari kata dasar "derita" yang berarti "keadaan yang menyedihkan - seperti kesengsaraan, penyakit - yang harus ditanggung." 6 Terkait dengan penderitaan, The American Heritage Dictionary Of The English Language, mengartikannya sebagai sakit secara jasmani, tapi bisa juga secara psikologis seperti tekanan emosi atau perasaan yang setiap orang berusaha untuk menghindarinya; atau sakit secara mental, psikologis dan jasmani. ${ }^{7}$ Kata "penderitaan"menurut Salim dibagi dalam empat

3 B. Kreysen Purba, "Menderita Karena Pilihan: Sebuah Renungan Tentang Imperatif Penderitaan Di Tengah Komunitas Yang Pluralistik", Jurnal TeologiStulos (Bandung: STTB,2010), 28.

4 Andy \& Rina (ed.), Batu-Batu Tersembunyi Dalam Pondasi Kita, Kisah Para Martir Sepanjang Abad (Surabaya: KDP, 2009), 244

5 Aulia Bintang Pratama, "Pembakaran Gereja Capai 1.000 Kasus Pasca Reformasi" dalam CNN Nasional, https://m.cnnindonesia.com, (akses, Rabu, 10 Oktober 2015)

6 Pusat Bahasa Departemen Pendidikan Nasional, Kamus Besar Bahasa Indonesia Edisi 3 (Jakarta: Balai Pustaka, 2003), 256.

7 B. Kreysen Purba, 'Suffering" The American Heritage Dictionary of The English Language, ed. Ke-4, Houghton Mifflin Company, 2009; Stulos Jurnal Teologi, (Bandung: STTB, 2010), 22. 
pengertian yaitu: menderita, dihukum, tahan, dan mengijinkan. ${ }^{8}$ Dari kata penderitaan Kamus Bahasa Indonesia I mengartikan penanggungan. ${ }^{9}$

Penderitaan merupakan bagian dari umat manusia di manapun ia berada baik di negara maju, maupun yang kurang maju, kecil maupun besar, komunis maupun kapitalis, agama maupun sekuler. Hanya bentuk, tingkatan dan penyebabnya saja yang berbeda-beda. ${ }^{10}$ Penderitaan melampaui horison waktu, ia ada dulu, sejak zaman dahulu kala sampai sekarang dan juga di masa mendatang. Penderitaan adalah fakta universal. Penderitaan adalah fakta yang tidak hanya universal tetapi juga "seolah-olah" abadi. ${ }^{11}$

\section{Perspektif Perjanjian Lama}

Dalam Perjanjian Lama "penderitaan" dipakai dalam AlkitabTerjemahanBaruIndonesia untuk menterjemahkan banyak kata yang artinya sakit, dukacita, malang, siksaan, dll. Dalam Alkitab penderitaan dianggap gangguan atas dunia ciptaan ini. ${ }^{12}$ Dalam Perjanjian Lama, ada tiga istilah yang sering dipakai untuk menjelaskan tentang "penderitaan."

Pertama, 'yasar'rs;y"(dipakai 34 kali dalam PL) artinya in binding them. ${ }^{13}$ Brown menterjemahkan tie, bind, dan imprison. ${ }^{14}$ Baker's Dictionary of Theology menjelaskan bahwa yasar mempunyai tujuan yaitu "to discipline" (Hos. 10:10), "to instruct" (Mzm.2:10), dan "to chasten" (Yer.6:8). ${ }^{15}$ Harris menjelaskan bahwa yasar juga dipakai dalam konteks sumpah dan kewajiban terhadap diri sendiri atau seseorang. ${ }^{16}$

Kedua, 'ana' $\square \square \square \square \square$ yang berarti oppresed. ${ }^{17}$ Brown menterjemahkan be bowed down, doing violence to, dan afflicted. ${ }^{18}$ Harrison mengartikan doing

8 Peter Salim, The Contemparary English-Indonesia Dictionary Volume 2 (Jakarta: Media Eka Pustaka, 2006), 2306.

9 Pusat Pembinaan Dan Pengembangan Bahasa Departemen Pendidikan Dan Kebudayaan, Kamus Bahasa Indonesia I (Jakarta: Departemen Pendidikan Dan Kebudayaan, 1983), 493.

10 Bedjo Lie, "Penderitaan Menurut Agama Buddha: Sebuah Tinjauan Kritis Dari Perspektif Kristen” (Artikel), www.gkri-exodus.org, 16 Juni 2011, 4.26PM.

11 Bedjo Lie, "Penderitaan Menurut Agama Buddha: ...

12 J.D. Douglas, Ensiklopedi Allkitab ..., 244.

13 John Joseph Owen, Analitycal Key to The Old Testament Vol. 4 (Isaiah-Malachi) (Grand Rapids, Michigan: Baker Book House, 1994), 780.

14 Francis Brown, Hebrew And English Lexicon (Lafayette, Indiana: Assosiated Publishers And Autors, Inc., 1978), 63.

15 Everett F. Harrison (ed.), Baker's Dictionary of Theology (Grand Rapids, Michigan: Baker Book House, 1975), 505.

16 R. Laird Harris, Theological Wordbook of The Old Testament Vol. 1 (Chicago: Moody Press, 1980), 61.

17 John Joseph Owen, Analitycal Key to The Old Testament Vol. 1 (Genesis-Joshua) (Grand Rapids, Michigan: Baker Book House, 1994), 57.

18 Francis Brown, Hebrew And English..., 776. 
violence to another (Kej.15:13), to humiliate (Bil. 24:24), dan to be afflicted (Mzm.107:17). ${ }^{19}$ R. Laird Harris menjelaskan bahwa kata ana IIIdalam Alkitab dipakai sebanyak 200 kali dengan pengertian dasar adalah to force atau to try to force submission, dan to punish or inflict pain upon sering dipakai dalam bentuk Piel. Dan kata ini biasanya digunakan bagaimana seseorang memperlakukan yang dianggap budak atau musuh, misalnya ketidaknyamanan Sarah atas penghinaan Hagar sehingga dia menindasnya (Kej. 16:6), tindakan Tuhan terhadap musuh Israel (Ul.26:6), penderitaan Kristus (Yes.53:4). ${ }^{20}$

Ketiga, 'sarar' $\square \square \square \square \square$ yang berarti distress. ${ }^{21}$ Brown menterjemahkan make narrow for, press hard upon, dan cause distress to. ${ }^{22}$ Haris mengemukakan bahwasarar menunjuk kepada sesuatu yang sempit atau mengikat. Sebuah tempat yang mungkin semakin sempit ketika semakin banyak orang yang mendiami. Sarar artinya membalut, mengikatkan. Membalut sebuah batu untuk menyandang (Ams 26:8), menusuk jarum pada mantel (Kel. 12:34), atau menambal kirbat anggur (Yos. 9:4). Hosea menggambarkan dosa Efraim yang akan membuat mereka terjepit (Hos 4:19), kesalahan Efraim dibungkus, dosanya disimpan (13:12). Sarar juga menunjuk kepada emosi yang tinggi karena tekanan dari luar oleh musuh, atau tekanan dari dalam karena salah mengambil keputusan (Kel. 32:7). ${ }^{23}$

Hal ini menunjukkan bahwa penderitaan itu dekat dengan manusia. Penderitaan membuat manusia menderita, terhimpit, terdesak, bahkan penderitaan itu dapat menusuk bagaikan jarum yang tertancap ke tubuh. Bahkan sesuatu yang tidak berwujud seperti emosi dan salah mengambil keputusan rentan membuat manusia menderita. Penyebabnya adalah dosa.

\section{Penderitaan Dalam Perspektif Perjanjian Baru}

Dalam Perjanjian Baru, ada dua istilah yang dipakai untuk menjelaskan tentang "penderitaan."

Pertama, kata Yunani paskho adalah istilah umum untuk sesuatu yang dilakukan terhadap seseorang. ${ }^{24}$ Sutanto mengartikan, mengalami, menderita, menderita kematian. ${ }^{25}$ Bromiley menjelaskan, pascho dalam konteks dunia Yunani dan Helenistik memiliki pengertian dasar yakni 1) mengalami sesuatu yang datang dari luar. "Sesuatu" yang dimaksudkan biasanya buruk, 2) dalam

19 Everett F. Harrison, (ed.), Baker's Dictionary..., 505.

20 R. Laird Harris, Theological Wordbook of The Old Testament Vol. 2 (Chicago: Moody Press, 1980), 682.

21 John Joseph Owen, Analitycal Key to The Old Testament Vol. 4 (Isaiah-Malachi) (Grand Rapids, Michigan: Baker Book House, 1994), 251.

22 Brown, Hebrew And English ..., 864.

23 R. Laird Harris, Theological Wordbook ..., 779.

24 J.D. Douglas, Ensiklopedi Allkitab ..., 244.

25 Hasan Sutanto, Perjanjian Baru Interlinier Konkordansi Jilid II, (Jakarta: LAI, 2006), 618 . 
hubungan dengan pengadilan menderita karena kesalahan, 3) menderita karena kejahatan adalah kemalangan dan tidak disukai. Dalam PB kata pascho dipakai 42 kali, sering dipakai untuk menjelaskan penderitaan Kristus tepatnyakematian Kristus dan penderitaan mereka yang menjadi pengikutNya. $^{26}$

Kedua, kata Yunani thlipsis mempunyai arti umum "tekanan," beban yang berat bagi hati orang. Kata itu dipakai juga mengenai siksaan besar (Mrk. 13:19, 2 Tes. 1:6, dab, Why. 7:14). ${ }^{27}$ Sutanto mengartikan "penindasan; kesusahan." ${ }^{28}$ Bromiley menjelaskan, thlipsis dalam konteks Yunani diartikan tekanan yang dialami secara fisik. Secara teologis, dalam LXX memiliki pengertian yang bervariasi yakni untuk keadaan yang sukar, permusuhan, menyebabkan sakit, menindas, bermusuhan, menghancurkan, dan tribulasi. Dalam PB, orang-orang percaya dan rasul-rasul mengalami penderitaan. Saudara-saudara (orang percaya) telah tersebar karena penganiayaan yang timbul sesudah Stefanus dihukum mati (Kis. 11:19). Paulus sebagai seorang rasul menderita adalah fakta penderitaan. ${ }^{29}$

"Penderitaan" atau passion dalam studi PB ialah penderitaan dan kematian Yesus; dan passion sebagai kisah penderitaan mencakup seluruh masa penderitaan Yesus mulai dari perjamuan akhir (Mrk. 14), penahanan, pengadilan, penyaliban dan pemakaman, sebagaimana dicatat dalam ke empat Injil. Tetapi, penggunaan istilah passion atau penderitaan Yesus itu hanya kita jumpai dalam Kisah Rasul 1:3. ${ }^{30}$

Riedel memakai istilah "sengsara," di dalam bahasa Yunani untuk kata "sengsara" itu digunakan perkataan pathema. Arti perkataan itu ialah suatu sengsara yang dialami dan yang ditahankan, sesuatu yang mendatangkan dukacita dan yang merugikan atau merusakkan kehidupan kita. Orang yang tengah menderita kesusahan besar, tiada gampang dapat mengerti perkataan Yesus: "Berbahagialah segala yang berdukacita, karena mereka itu akan dihiburkan" (Mat. 5:4). Akan tetapi kata-kata itu bukanlah suatu kebenaran yang umum, karena yang dimaksudkan di sini hanyalah orang yang berdukacita secara istimewa saja. Dukacita itu timbul di dalam hati orang, oleh karena mereka itu sudah mengerti, bahwa mereka itu tidak berlayak bagi kerajaan Allah. Dukacita yang demikian akan mendatangkan tobat. Orang yang bertobat itu akan dijanjikan oleh Yesus, bahwa mereka itu akan dihiburkan juga. Sengsara yang diderita oleh orang Kristen boleh juga menjadi berkat. Di dalam dunia ini banyak terdapat barang yang diingini dan perihal yang mendatangkan bahaya bagi orang yang beriman, oleh karena sengsara,

26 Geoffrey W. Bromiley, Theological Dictionary Of The New Testament (Grand Rapids, Michigan: William E. Eerdmans Publishing Company, 1986), 798-799.

27 J.D. Douglas, Ensiklopedi Allkitab ..., 244.

28 Hasan Sutanto, Perjanjian Baru Interlinier..., 374.

29 Geoffrey W. Bromiley, Theological Dictionary..., 334.

30 W.R.F. Browning, Kamus Alkitab (Jakarta: BPK Gunung Mulia, 2008), 324. 
kita diajar untuk melepaskan segala sesuatu yang menjadi rintangan untuk keselamatan kita (Luk. 14:33). Bila orang yang beriman jatuh ke dalam berbagai-bagai pencobaan, mereka itu harus bersukacita, oleh karena ujian imannya mengerjakan tekun (Yak. 1:2-3). ${ }^{31}$

Jadi, sengsara adalah segala sesuatu yang kita alami yang tidak menyenangkan, menyakitkan, merugikan baik yang disebabkan oleh orang lain (eksternal) maupun diri sendiri (internal). Dalam hal ini, sengsara diakibatkan karena mengikut Kristus dan setiap orang percaya pasti akan mengalami sengsara. Yesus menuntut iman dari orang Krsiten yang menderita sengsara karena Ia sendiri juga mengalami sengsara yang berat, sehingga ia ditinggalkan Bapa-Nya.

\section{Aspek-Aspek Penderitaan}

Menurut UU No. 23/1992, kesehatan adalah suatu keadaan sejahtera dari badan (jasmani), jiwa (rohani) dan sosial yang memungkinkan setiap orang hidup produktif secara sosial dan ekonomis. Sedangkan menurut WHO (1974), kesehatan adalah keadaan yang sempurna baik fisik, mental, sosial bukan hanya bebas dari penyakit, cacat, dan kelemahan. ${ }^{32}$ Sebaliknya penderitaan timbul sebagai akibat dari sakit yang dialami oleh seseorang. Sakit dapat diartikan sebagai sakit badan atau jasmani, dan dapat juga berupa sakit jiwa atau rohani. ${ }^{33}$

\section{Fisik}

Penderitaan fisik dalam arti yang biasanya mencakup tidak hanya "khas sensorik" pengalaman fisik rasa sakit tetapi juga pengalaman tubuh yang lainnya yang tidak menyenangkan. Dalam arti yang luas, yaitu untuk setiap emosi, perasaan tidak menyenangkan atau sensasi. ${ }^{34}$ Sebagian besar rasa sakit fisik yang dialami manusia mengingatkan adanya sesuatu yang tidak beres. ${ }^{35}$ Penderitaan fisik, misalnya tidak memiliki cukup sandang, pangan, papan, terkena penyakit, kecelakaan. Pikiran yang tidak dapat dikontrol yang terus menerus menilai penderitaan maka penderitaan fisik dapat menyebabkan penderitaan psikologis. Penderitaan fisik yang dialami manusia diatasi secara

31 K. Riedel, Kamus Istilah Teologia (Jakarta: Badan Penerbit Kristen, 1952), 184.

32 Sehat Sakit Dilihat Dari Perseptual Budaya Keperawatan Sebagai Profesi, Konsep Sehat-Sakit (Artikel) http://perawattegal.wordpress.com/2009/08/31/konsep-sehat-sakit/, 31 Agustus 2008, 1.30am.

${ }^{33}$ Manusia Dan Penderitaan http://youmy88.blogspot.com/2011/03/manusia-danpenderitaan.html.

34 http://mantapblogs.blogspot.com....

35 Simon \& Christoper Denes, Masalah-Masalah Moral Sosial Aktual Dalam Perspektif Iman Kristen (Yogyakarta: Kanisius, 2000), 41. 
medis untuk mengurangi atau menyembuhkan. ${ }^{36}$ Tentang penderitaan fisik Martin Luther menjelaskan sebagai berikut:

\begin{abstract}
In the which man who are carnal are overcome; they fail because of their concern for physical goods, for things, for the body, for reputation, and they depart from God, lose hope because of their impatience, and thus deliver themselves up to the flesh and forsake God. Of such people the apostle says, Eph. 4:19: "They have become callous and have given themselves up to the licentiousness." 37
\end{abstract}

Penderitaan jasmani dapat menyebabkan penderitaan rohani walaupun tidak mutlak. Seorang yang imannya lemah setelah mengalami penderitaan jasmani, dapat pula mengalami penderitaan rohani. Sebaliknya, seorang yang sungguh beriman kepada Allah akan dapat menerima penderitaannya dengan ucapan syukur, sehingga rohaninya dapat tidak terganggu sama sekali. Dalam beberapa kasus tertentu, kehidupan rohani orang tersebut justru bertumbuh setelah musibah terjadi dalam kehidupannya. Mengenai hal ini, bahwa seseorang yang menderita perlu sekali memfokuskan pandangannya pada Kristus yang telah lebih dahulu menderita di salib.

\title{
Jiwa
}

Jika ternyata kerohanian seseorang dalam keadaan buruk/sakit, maka perlu tindakan untuk mencari penyebabnya dan bagaimana mengatasinya sehingga dapat menghindarkan akibat yang lebih buruk lagi. ${ }^{38}$ Tentang penderitaan jiwa Martin Luther menjelaskan sebagai berikut:

\begin{abstract}
Where in all of one's self righteousness and wisdom in which people trust are devoured and done away. Of thesesavior says, in a mystical way, "When a strong man fully armed ... but when one stronger than he assails him and overcomes him, he takes away his armor and blinds him and divides his spoil" (Luk. 11:2122 ), that is, he will strip a man who is fortified with his own righteousness and will teach him that they are to be used for the common good and not for his own pleasure. $^{39}$
\end{abstract}

Penderitaan rohani apabila tidak ditangani dengan segera dan tuntas, akan dapat menyebabkan penderitaan jasmani. Penderitaan rohani dapat terjadi akibat serangan terhadap pribadi seseorang: penghinaan, makian, perkosaan, ancaman, kebencian, ketidakpedulian, ditelantarkan, dan lain-lain. Penderitaan rohani juga dapat terjadi karena hambatan dan kegagalan dalam berkarya, kehidupan rumah tangga, dan dalam kehidupan bermasyarakat.

36 http://id.wikipedia.org/wiki/siksaan, 25 Juli 2011, 3.37PM.

37 Martin Luther,... Works Volume 25, 293.

38 Pembentukan Rohani Kristen 6: Penyakit Rohani (Artikel) http://pesta.org/prk_pel06, 20 Juli 2011, 1.11am.

Martin Luther,... Works Volume 25, 293. 


\section{Analisis Historis Surat 1 Petrus}

Dalam Yohanes 1:35-42 diceritakan tentang pertobatan Petrus. Kemudian ia dipanggil menjadi hamba Tuhan (Mat. 4:8-20, Mrk. 1:16-18, Luk. 5:11). Petrus adalah murid yang paling dekat dengan Yesus (Mrk. 9:2, 5:37, 14:33). Sebelum pencurahan Roh Kudus, Petrus menjadi pemimpin para murid. Petrus berbicara dengan berani kepada orang banyak (Kis. 3:12), pula kepada pemimpin-pemimpin agama Yahudi (Kis. 4:8).Dalam Analisa Historis penulis akan membahas mengenai penulis, waktu penulisan, alamat dan tempat penulisan, maksud dan tujuan penulisan dan karakteristik surat 1 Petrus.

\section{Penulis Surat 1 Petrus}

Surat 1 Petrus 1:1 berkata: "Dari Petrus, rasul Yesus Kristus," jelaslah bahwa yang dimaksudkan adalah Petrus yang sering kali disebutkan dalam Injil dan Kisah Para Rasul.Sebenarnya namanya adalah "Simon" (Kis. 15:4, 2 Ptr. 1:1, Mrk. 1:16, Yoh. 1:45). ${ }^{40}$

Tenney memberi penjelasan tentang penulis surat 1 Petrus sebagai berikut:Simon Petrus, penulis surat ini, adalah rasul Kristus yang paling terkenal. Seperti kebanyakan dari rekan-rekannya, ia adalah orang Galilea, seorang nelayan, yang dibawa kepada Yesus pada awal pelayanan-Nya (Yoh. 1:41-42). Simon adalah namanya yang sesungguhnya; Petrus (batu karang) adalah suatu julukan yang diberikan kepadanya oleh Yesus, yang meramalkan bahwa sifatnya yang mudah terbawa perasaan dan mudah bimbang akan menjadi teguh dan dapat diandalkan seperti sebuah batu karang. ${ }^{41}$

Selain itu, Guthrie juga menjelaskan bahwa kuatnya kesaksian bapakbapak gereja atas kepenulisan Petrus dan tidak adanya pertentangan di antara mereka dalam hal ini, sangat mendukung klaim bahwa surat ini asli tulisan Petrus, sehingga sangat mengejutkan bila hal ini masih diragukan. ${ }^{42}$

Petrus adalah murid Yesus yang pertama dipanggil; ia selalu disebut yang pertama dalam urutan murid-murid; ia juga dari ketiga murid yang merupakan kelompok akrab dengan guru mereka (Mrk. 5:37; 9:2; 14:33; bnd 13:3). Tindak pelayanannya yang didorong gelora hatinya, sering dilukiskan dalam Alkitab (bnd. Mat. 14:28; Mrk. 14:29; Luk. 5:8; Yoh. 21:7), dan dia bertindak sebagai juru bicara dari ke-12 murid itu (Mat. 15:15; 18:21; Mrk. 1:36 dab: 8:29; 9:5; 10:28; 11:21; 14:29 dab: Luk. 5:5; 12:41). ${ }^{43}$ Dengan demikian tidak ada alasan untuk meragukan Petrus, rasulYesus Kristus, adalah penulis surat 1 Petrus ini.

40 Ola Tulluan, Introduksi Perjanjian Baru (Batu: Departemen Literatur YPPII, 1999), 261-162.

41 Merril C. Tenney, Survey Perjanjian Baru (Malang: Gandum Mas, 2006), 430.

42 Donald Guthrie, Pengantar Perjanjian Baru Volume 3 (Surabaya: Momentum, 2009), 89.

43 J. D. Douglas, Ensiklopedi Alkitab Masa Kini Jilid 2 (Jakarta: Yayasan Bina Kasih/OMF, 2007), 256. 


\section{Alamat dan Tujuan Penulisan}

Alamat surat 1 Petrus adalah "orang-orang pendatang, yang tersebar di Pontus, Galatia, Kapadokia, Asia Kecil dan Bitinia, yaitu orang-orang yang dipilih sesuai dengan rencana Allah" $(1: 1-2) .{ }^{44}$ Ada tradisi dini dan kuat yang menyebutkan bahwa masa akhir dari hidupnya dijalani Petrus di Roma. ${ }^{45}$

Tulluan menjelaskan tentang tempat penulisan 1Petrus yaitupenafsir sependapat bahwa surat ini ditulis tidak lama sebelum Petrus mati syahid di bawah Kaisar Nero. Rupanya penganiayaan yang dialami oleh jemaat belum menjadi terorganisir, dan belum ada tanda bahwa orang-orang Kristen sudah dibunuh. Tetapi jelas bahwa mereka hidup di bawah tekanan. Kebanyakan panafsir berpendapat bahwa surat ini ditulis sebelum penganiayaan di bawah Kaisar Nero menjadi berat, yaitu pada pertengahan $64 .{ }^{46}$

Maksud dan tujuan penulisan surat 1 Petrus adalah, menurut 1 Petrus 5:12, untuk menasehati dan meyakinkan, bahwa ini adalah kasih karunia yang benar-benar dari Allah.Nasihat ini sangat perlu karena para penerima dihambat $(1: 6-7 ; 3: 14,17 ; 1: 12-14 ; 5: 8-9)$, dan diejek $(3: 9,16)$. Hal ini terjadi karena Kristus $(4: 14,16)$. Petrus menasehati mereka tentang sikap mereka terhadap pemerintah dan negara. Hal ini menunjukkan bahwa mereka sedang mengalami tekanan dari pihak lain (2:13-17). Juga ada urusan interen yang tidak beres, dimana perlu banyak nasihat (2:11 dst., 4:1-5, 5:2-3). ${ }^{47}$

Guthrie juga memberi penjelasan yang samayaitu dengan mengasumsikan Petrus menulis kepada kaum pilihan Allah yang "tersebar di Pontus, Galatia, Kapadokia, Asia Kecil dan Bitinia" (1 Ptr. 1:1. Surat ini menekankan pengharapan, dan Petrus ingin mendorong jemaat hidup sesuai dengan pengharapan yang mereka terima melalui Kristus. Ia memberikan bimbingan praktis bagi relasi mereka dengan orang lain dan secara khusus mendorong mereka tetap bersukacita dalam penderitaan demi kepentingan Kristus. Tetapi, meski terutama memberikan dorongan, tidak jarang penulis memasukkan pertimbangan teologis untuk memperkuat nasihat etisnya. Terkadang ia menghadirkan karya Kristus untuk memicu orang Kristen agar tahan menderita, sementara pada waktu yang sama memaparkan arti penderitaan secara lebih mendasar. ${ }^{48}$

Jadi, surat 1 Petrus ini ditulis kepada orang-orang pendatang, yang tersebar di Pontus, Galatia, Kapadokia, Asia Kecil dan Bitinia, yaitu orangorang yang dipilih sesuai dengan rencana Allah, Bapa kita, mereka sedang dalam penganiayaan karena iman mereka kepada Allah.

44 Donald Guthrie, Pengantar Perjanjian..., 106.

45 Charles F. Pfeiffer \& Everett F Harrison, The Wycliffe Bible Commentary (Malang: Gandum Mas, 2001),992.

46 Ola Tulluan, Introduksi Perjanjian ..., 264-265.

47 Ibid., 264.

48 Donald Guthrie, Pengantar Perjanjian..., 106. 


\begin{abstract}
Analisa Konteks
Data-data historis yang paling utama terkait dengan penganiayaan (1:6 dab; 3:13-17; 4:12-19: 5:9). Dalam kedua bagian pertama disajikan cobaancobaan, dan penderitaan tidak adil yang mungkin saja terjadi; dalam kedua bagian terakhir disajikan ancaman penderitaan yang dahsyat, sedemikian rupa sehingga ada ahli berpendapat bahwa 4:12 ditulis pada masa yang kemudian. ${ }^{49}$ Tapi kosa katanya sangat serupa; dalam kedua bagian ini dipakai peirasmos, "pencobaan" (1:6 dan 4:12); penganiayaan merupakan alasan untuk bergembira $(1: 6 ; 4: 13)$; kata bahagia yang sama diucapkan $(3: 14 ; 4: 14)$; kemuliaan sebagai dampak penderitaan karena melakukan yang baik, atau sebagai seorang Kristen, diumumkan $(3: 17$; 4:16); penderitaan orang Kristen yang tidak bersalah dihubungkan dengan kehendak Allah $(3: 17 ; 4: 19)$ dan teladan penderitaan Kristus diuraikan $(1: 11 ; 3: 18 ; 4: 13)$. Para pembaca dinasehati supaya jangan terkejut karena api siksaan yang bernyala-nyala menimpa mereka (4:12), dan penderitaan itu telah mereka ketahui (bnd 1:6) ${ }^{50}$

Penderitaan di dalam daging (4:1-6). Ada kontras yang jelas antara penderitaan daging dan hidup di dalam daging. Teladan Kristus harus membuat kita siap menderita dalam daging jika Allah menghendakinya dan membuat kita dengan teguh menolak hidup dalam daging. Mereka yang berkanjang di dalam nafsu-nafsu daging harus siap bertanggung jawab kepada Hakim Ilahi. ${ }^{51}$

Jika dihina karena nama Kristus, orang Kristen harus memuliakan nama Allah. ${ }^{52}$ Petrus dengan jelas menasehatkan umat Allah yang ada di perantauanmengenai cara hidup yang benar sebagai umat yang telah diselamatkan Yesus Kristus. Ia juga memberikan nasehat mengenai cara hidup yang benar di tengah-tengah orang yang belum percaya. Di dalam nasehatnya ia juga meminta agar penatua sungguh-sungguh memelihara dan menggembalakan umat-Nya sekalipun dalam penganiayaan.
\end{abstract}

\title{
Tujuan Penderitaan
}

Dalam bagian ini Petrus mulai dengan ungkapan, "saudara-saudara yang kekasih.'Kata 'Agaphtoi - agapetoi-dari akar kata 'Agaphtos- agapetosmerupakan kata sifat sebagai ganti penunjuk orang, oleh karena itu diterjemahkansaudara-saudara yang dikasihi; yang satu-satunya dikasihi. ${ }^{53}$

Istilah perintahmh. xeni,zesqe- me ksenizesthe-atau don't be surprised adalah suatu penjelasan lanjut dari w`j xe,nou u`mi/n sumbai,nontoj- hos ksenu

49 J. D. Douglas, Ensiklopedi Alkitab..., 259.

50 Ibid

51 Donald Guthrie, Pengantar Perjanjian..., 126.

52 Ibid 2006), 7 .

53 Hasan Sutanto, Perjanjian Baru Interlinier Konkordansi Jilid II (Jakarta: LAI, 
humin sumbainontos- atau "seolah-olah ada sesuatu yang luar biasa terjadi atas kamu." ${ }^{54}$ Suatu istilah yang tidak umum dipakai dalam Perjanjian Baru, dalam Kisah Para Rasul (tujuh kali), Ibrani (satu kali) dan 1 Petrus (dua kali).Penggunaan istilah ini dalam arah menyatakan kemuliaan Tuhan (1Ptr. $4: 11,14,16$ ), eskatologi dan penghakiman orang-orang jahat. ${ }^{55}$

Lebih lanjut Kistemaker menjelaskan demikian:"Do not be surprised." In the Greek, Peter use the same verb as in verse 4. There he writes that the pagan world thinks it strange that Christian do not participate in their riotous living; in reaction to this refusal the unbelieving world heaps abuse on the believers. Now Peter says that Christian should be not surprised when they endure persecution. Jesus warns them that unbelieving world hates his followers (John 15:18-19); 17:14; and compare 1 John 3:13. Therefore, having this warning, Christian should not be astonished when they must suffer persecution." 56

Dengan demikian frase“janganlah kamu heran" memiliki hubungan yang sangat erat dengan 1Petrus 4:1, yang menjelaskan bahwa Kristus telah menderita penderitaan badani, oleh karena itu janganlah heran apabila kamu (orang percaya) mengalami siksaan, sebab Kristuspun telah menderita penderitaan badani.

Kata purw,sei- purosei-(noun, dative) artinyaat painful trial atau pembakaran, siksaan yang hebat, siksaan yang menyakitkan. ${ }^{57}$ Michaels menterjemahkan the trial of the end-time, the eschatological ordeal or test. ${ }^{58}$ Dativedalam purw,sei- purosei-menjelaskan sebagai penyebab dari penderitaan orang percayayang dinyataan Petrus dalam ayat 12, "janganlah kamu heran akan nyala api siksaan." ${ }^{, 59}$ Wiersbe menjelaskan bahwa api siksaan yang disebutkan dalam 1Petrus 4:12 timbul karena kita setia kepada Allah dan berdiri di atas hal yang benar. Api siksaan ini datang karena kita mempertahankan nama Kristus sehingga dunia yang hilang ini menyerang kita.Kristus memberitahukan murid-murid-Nya bahwa orang-orang akan

54 J. Ramsey Michaels, Word Biblical Commentary 1 Peter (Waco, Texas: Word Books Publisher, 1988), 259.

55 Edwin A. Blum, The Expositor's Bible Commentary Vol. 12, Hebrews - Revelation (Grand Rapids, Michigan: Zondervan Publishing House, 1981), 247.

56 Simon J. Kistemaker, New Testament Commentary Peter and Jude (Grand Rapids, Michigan: Baker Book House,1987), 173.

57 Hasan Sutanto, Perjanjian Baru Interlinier..., 690.

58 J. Ramsey Michaels, Word Biblical..., 260.

59 Gambaran tentang "api" sering diterapkan sebagai ujian atau penganiayaan, juga dalam percakapan sehari-hari. "Ia benar-benar mengalami api pencobaan," merupakan pernyataan yang khas untuk menggambarkan seseorang yang mengalami kesulitan secara pribadi. Dalam Perjanjian Lama, api adalah simbol kesucian Allah dan kehadiran Allah. Api di atas mezbah membakar korban (Ibr. 12:28-29). Akan tetapi Petrus melihat gambaran tentang api sebagai suatu proses pemurnian, bukan suatu penghakiman ilahi (1 Ptr. 1:7; Ayb. 23:10). Warren W. Wiersbe, Pengharapan Di Dalam Kristus (Bandung: Kalam Hidup, 1982), 124. 
menganiaya mereka, sebagaimana mereka telah menganiaya Dia, karena penganiaya-penganiaya mereka tidak mengenal Allah (Yoh. 15:20-21). ${ }^{60}$

Tujuan Petrus menuliskan frase "janganlah kamu heran akan nyala api siksaan" yakni untuk mengingatkan para pembaca (orang percaya) agar jangan terperanjat, kelihatan menunjuk kepada ujian yang lebih keras daripada yang mereka alami selama ini. Ayat ini cukup cocok dengan penganiayaan di bawah perintah Nero ketika dimana orang-orang Kristen dibakar pada malam hari sebagai alat penerangan di taman kerajaan. Petrus, yang berada di Roma, kuatir peristiwa ini cepat menjalar ke semua propinsi. ${ }^{61}$

Mengenai penganiayaan terhadap orang percaya dalam ayat ini, Wiersbe memberikan komentar yakni: penganiayaan bukanlah sesuatu yang asing dalam kehidupan Kristen. Sepanjang sejarah, umat Allah telah mengalami penderitaan di bawah penguasa dunia yang belum percaya. Orangorang Kristen berbeda dengan orang-orang yang belum percaya (2Kor. 6:1418), dan perbedaan ini menyebabkan cara hidup yang berbeda pula. Banyak hal yang terjadi di dunia ini dibangun di atas dasar kebohongan, kesombongan, kesenangan duniawi dan keinginan untuk "memperoleh lebih banyak lagi." Seorang Kristen sungguh-sungguh akan membangun kehidupannya atas dasar kebenaran, kerendahan hati, kekudusan, dan keinginan untuk memuliakan Allah. ${ }^{62}$

Jadi,walaupun bertentangan dengan dasar hidup orang-orang duniawi, orang percaya harus tetap membangun kehidupannya di atas dasar kebenaran Kristus, karena itulah yang dikehendaki-Nya bagi kita.

Selanjutnya katapeirasmo.n-peirasmon-(accusative), NIV memakai kata suffering atau diterjemahkan pengujian, ujian, penggodaan, godaan. ${ }^{63}$ Bromiley mengartikan testing atau temptation. 1Petrus 4:12 refer more specifically to the test of persecution, but argues that this should be meet the joy because it means participation in the suffering of Christ. ${ }^{64} \mathrm{Jadi}$ istilah ini menujukkan bahwa adanya pengujian, ujian, penggodaan, godaan yang akan dihadapi orang percaya. Penderitaan yang dialami orang percaya sebagai partisipasi di dalam penderitaan Kristus.

Kata ginome,nh|- ginomene-diterjemahkan ada, datang, dan muncul. ${ }^{65}$ Presentparticipleberarti hal tersebut dilakukan pada waktu yang sama dengan apa yang disebut dalam kata induk kalimat. ${ }^{66}$

\footnotetext{
60 Ibid., 125.

61 Charles F. Pfeiffer \& Everett F. Harrison, The Wycliffe Bible Commentary Vel. 3 (Malang: Gandum Mas, 2001), 1008.

62 Warren W. Wiersbe, Pengharapan ..., 123.

63 Ibid, 625.

64 Geoffrey W. Bromiley, Theological Dictionary of The New Testament (Grand Rapids, Michigan: William B. Eerdmans Publishing Company, 1986), 822.

65 Hasan Sutanto, Perjanjian Baru Interlinier..., 166.

66 Erni Takaliuang, Eksposisi Injil Matius (Diktat Kuliah), (Batu: Institut Injil Indonesia, 2008)82.
} 
Dari penjelasan di atas tentang istilahpro.j peirasmo.nu`mi/nginome,nhpros peirasmon humin ginomene- untuk menjelaskan adanya penderitaan yang selalu mengarah/menuju orang percaya sebab antara orang percaya dengan penderitaan memiliki hubungan yang erat. Penderitaan yang dialami karena menyatakan kemuliaan Allah, dan supaya Kristus dikuduskan di dalam hati orang percaya sebagai Tuhan. Dalam segala situasi, senantiasa siap sedia memberi pertanggunganjawab kepada tiap-tiap orang yang meminta pertanggungan jawab tentang pengharapanyang ada padamu, tetapi haruslah dengan lemah lembut dan hormat (1 Ptr. 3:15).

Kata w`j- hos-kata penghubung yang menyatakan waktu ${ }^{67}$ yang diterjemahkan seolah-olah, seperti dan ketika, ${ }^{68}$ dan kataxe,nou- ksenou(adjective) diterjemahkan asing, heran, yang memberi tumpangan. ${ }^{69}$ Drewes menterjemahkan asing, luar biasa. ${ }^{70}$

Berikutnya kata sumbai,nontoj-sumbainontos diterjemahkan terjadi. ${ }^{71}$ Kata "terjadi" penting artinya: sebenarnya kata ini berarti "pergi bersamasama." Penganiayaan dan pencobaan tidak sekedar "terjadi" dalam arti secara kebetulan." Penganiayaan dan pencobaan adalah bagian dari rencana Allah, dan Ia mengendalikan. Keduanya merupakan bagian dari Roma 8:28 dan akan mendatangkan kebaikan jika kita membiarkan Allah bekerja menurut kehendak-Nya."72

Dengan demikian, bahwa penderitaan yang terjadi terhadap orang percaya bukanlah suatu kebetulan melainkansuatu perintah untuk turut menderita bersama Kristus.Penderitaan dan kesesakan yang dialami karena perjuangan iman yang diijinkan oleh Tuhan untuk membuktikan kemurnian iman (1Ptr. 1:7). Ketika sesuatu yang tidak diharapkan terjadi, ketika penderitaan datang,orang Kristen tidak perlu mempertanyakan apalagi meragukan pemeliharaan Tuhan, sebab Allah mengontrol setiap situasi dan Ia memiliki kuasa untuk menopang orang percaya dari penderitaan yang akan datang. Allah dapat memakai penderitaan untuk memurnikan iman. Orang Kristen harus mengerti bahwa Allah mampu melihat iman yang benar dan iman yang pura-pura dan menggunakan penderitaan sebagai instrumen untuk mencapai tujuan-Nya.

67 Erni Takaliuang, Eksposisi..., 86.

68 Hasan Sutanto, Perjanjian Baru Interlinier..., 830.

69 Ibid., 543

70 B. F. Drewes, Kunci Bahasa Yunani Perjanjian Baru Surat Roma Hingga Kitab Wahyu (Jakarta: BPK Gunung Mulia, 2006), 331.

71 Hasan Sutanto, Perjanjian Baru Interlinier ..., 727.

72 Warren W. Wiersbe, Pengharapan..., 125. 


\section{Dasar Penderitaan}

Kata "tetapi" untuk mempertentangkan frase "janganlah kamu heran" yang terdapat di ayat 12, dengan frase "bersukacitalah" dalam ayat 13.Pada ayat 13 dan 14, Petrus menyebut sukacita empat kali dengan memakai kata yang hampir bersamaan. "Bersukacitalah ... bergembira dan bersukacita ... Berbahagialah ..." Kata ini berarti sangat penting megingat kondisi jemaat yang sedang dalam penganiayaan. Kata "bersukacitalah" dalam bahasa Yunanicai,rete- khairete-(NIV) rejoice, Sutanto menterjemahkan dengan bersukacita, salam, dan memberi salam. ${ }^{73}$ Kata rejoice atau "bersukacitalah" dalam bentuk presentactiveimperative berarti suatu perintah atau dorongan yang harus dilakukan supaya orang percaya tetap bersukacita sekalipun mereka mengalami penderitaan dan siksaan dari orang-orang yang tidak mengenal Tuhan.cai,rw artinya "to rejoice," "to be merry," "joy."Dalam PL the experience and expression of joy are close, as the term for joy...and it expression show. Joy expresses the whole person and aim at sharing, as in fiesta show. God's work of salvation is a chief occasion (Pss. 5:11)...God Himself rejoice (Is. 65:19), and thanks giving demand joy (Dt. 16:13). ... Old Testament joy culminates in eschatology (Joel 2:22).cai,rw dalam PB, the participle "full of joy." Even trials are an occasion of joy (Jms. 1:2) suffering is a testing of faith (1Ptr. 1:6-7) with a Christological basis (2:20; 4:12). One should not just rejoice "in" suffering but "at" suffering (Acts 5:41). ${ }^{74}$

Dari kutipan di atas bahwa rejoice atau sukacita lahir dari pengenalan akan Tuhan, akan suatu pengharapan untuk masa yang akan datang. Sukacita yang tidak dipengaruhi oleh situasi dan kondisi apapun yang dialami oleh seseorang. Seorang yang memiliki pengenalan yang benar akan Tuhan mampu bersukacita di dalam penderitaan dan mampu bersukacita terhadappenderitaan itu sendiri.

Kata koinwnei/te- koinoneite-(present, active, indicative) dari kata dasar koinwnew- koinoneo-diterjemahkan mendapat bagian, mengambil bagian, dan memberi bagian. ${ }^{75}$ Drewes menterjemahkan mengambil bagian dalam, ${ }^{76}$ sedangkan Bromiley menterjemahkan to share in, to impart, participation, impartation, or fellowship. ${ }^{77}$ Butler menjelaskan bahwa Koinonia berarti "persekutuan." Arti Koinoniadekat dengan 'kebersamaan pikiran dan pandangan,' yaitu sebuah hubungan antara dua pribadi Kristen atau komunitas-komunitas Kristen sebagai akibat dari partisipasi di dalam komunitas dan realita yang sama. 'Koinonia kepada yang lain berkaitan dengan koinonia kita kepada Allah di dalam Kristus'. Dengan demikian

73 Warren W. Wiersbe, Pengharapan ..., 806.

Geoffrey W. Bromiley, Theological Dictionary..., 1299.

Hasan Sutanto, Perjanjian Baru Interlinier..., 545.

B. F. Drewes, Kunci Bahasa Yunani..., 331.

Geoffrey W. Bromiley, Theological Dictionary..., 448. 
pengertian ini menjadi model memahami sifat gereja, seperti sejalan dengan pemahaman Perjanjian Baru. ${ }^{78}$

Katatoi/j- tois-kata sandang tertentu yang selalu ditulis di depan kata bendanya dalam bentuk datif untuk menyatakan kepemilikan kepada Cristou Khristou.Khristou artinya Kristus, Mesias. Kristus berarti Dia yang telah diurapi. Kata Kristus merupakan terjemahan bahasa Yunani untuk kata Mesias di bahasa Ibrani dan Aram. Kristus adalah nama diri Tuhan Yesus, sedangkan Mesias adalah sebutan kehormatan. ${ }^{79}$ Senada dengan itu Wiersbe menjelaskan demikian" Penderitaan kita berarti persekutuan dengan Kristus. Sesungguhnya menderita dengan Kristus dan diperlakukan oleh dunia seperti dunia memperlakukan Dia, adalah suatu kehormatan dan hak istimewa. "Persekutuan dalam penderitaan-Nya" adalah pemberian dari Allah (Fil. 1:29; 3:10). Tidak setiap orang percaya bertumbuh ke arah mana Allah mempercayai dia dengan pengalaman semacam ini, karena itu kita harus bersukacita apabila hak istimewa ini datang kepada kita." 80

Dengan kata lain, koinonia adalah persekutuan orang percaya dengan Kristus atau terhisap di dalam persekutuan dengan Kristus oleh karena itu penderitaan kita juga adalah penderitaan Kristus.

Istilah avpokalu,yei - apokalupsei - (bahasa Yunani)akar kataavpokalu,yij- apokalupsis -diterjemahkan wahyu, penerangan, penampakan. ${ }^{81}$ Menurut Browning wahyu/penyataan, pengetahuan baru yang diberikan tanpa si penerima memikirkan dan menyimpulkannya. Sebagai yang demikian itu, penyataan adalah karunia ilahi (Mat. 16:17), tetapi lalu dapat diteruskan kepada orang lain (Gal. 1:15-17). Cara mendapatkan penyataan itu mungkin melalui penglihatan (Yer. 1:11-13), atau melalui pemahaman kejadian-kejadian dalam sejarah (Mzm. 11:6). ${ }^{82}$

Jadi, pemahaman tentang penyataan dalam kaitan dengan ayat 13 yaitu bahwa penderitaan yang ditanggung oleh orang percaya karena mengikut Yesus akan memurnikan imannya. Hal yang menarik adalah bahwa hidup manusia harus ditata oleh kepercayaan dan khidmat mengenai semua apa yang dinyatakan Allah kepadanya, yang membimbing kepada kepatuhan yang sungguh mengenai segala perintah yang terkandung di dalam penyataan.

Kuatnya dorongan eskatologis nampak jelas dalam surat 1Petrus dalam "kemuliaan" - doxa. Istilah doxa dalam surat 1 Petrus memiliki arti eskatologis, yaitu kemuliaan Kristus (1:21) yang akan dinyatakan pada akhir zaman $(4: 13 ; 5: 1)$. Orang-orang yang mengimani Kristus dipanggil untuk

\footnotetext{
Sinclair B. Ferguson \& David F. Wright (ed.), New Dictionary of Theology Jilid 2 (Malang: SAAT, 2009), 266.

79 Hasan Sutanto, Perjanjian Baru Interlinier..., 818.

81 Ibid, 100

Warren W. Wiersbe, Pengharapan..., 126.

82 W. R. F. Browning, Kamus Alkitab (Jakarta: BPK Gunung Mulia, 2008), 475.
} 
mengambil bagian dalam kemuliaan Kristus itu $(5: 1) .{ }^{83}$ Kata do,xhj- doxes (genetive) diterjemahkan cahaya terang, keindahan, kemuliaan, kuasa yang mulia, refleksi, kebesaran, kebenaran, pujian, kebanggaan, dan kata auvtou autou -(genetive) menunjuk kepada pemilik kemuliaan yaitu Allah sendiri. Mengenai istilah ini Bromiley menjelaskan yaitu 1)doxa as the Divine Mode of Being (Lk. 2:9; 9:31-32; 2:14; Acts 22:11; 12:23; Rev. 15:8; 21:23; Gal. 5:1; 1 Ptr. 4:11).2) The doxa of Jesus.Doxa to Christ in the same way as to God. doxa then reflects all the dynamism of the relation of God and Christ (Rm. 6:4; 1 Tim. 3:16; Acts 7:55).3) The believer and doxa. The righteousness will shine (Dan. 12:3; Mt. 13:43; Phil. 3:21). ${ }^{84}$

Dengan demikian, katadoxa adalah untuk menjelaskan penyataan sifat dan kehadiran Allah dalam diri dan pekerjaan Yesus Kristus. Ia adalah cahaya kemuliaan Allah. kemuliaan Allah yang nampak pada wajah Yesus Kristus masih harus dilihat dan dipantulkan oleh orang percaya. Kemuliaan itu teristimewa dialami baik pada waktu kini (1 Ptr. 4:14) maupun di waktu yang akan datang kelak (Rm. 8:18) oleh mereka yang menderita bersama Kristus. ${ }^{85}$

Penyataan kemuliaan Kristus menjadi alasan untuk bersukacita. Kata "bersukacita" pada bagian ini berbeda dengan kata "bersukacita" yang pertama, walaupun menggunakan kata yang sama.Frase "kamu boleh bersukacita" dalam bahasa Yunanicarh/te- kharete -(aorist, passive subjunctif) artinya bersukacita, salam, dan memberi salam. Penggunaan subjunctif pada kata cai,rw- kairo -menunjukkan bahwa kata ini mengandung satu ajakan yang disengaja untuk bersukacita karena telah menerima penyataan kemuliaan Kristus.Pengertian lain, arah pasif itu berarti bahwa sukacita orang percaya dikerjakan oleh Yesus sendiri. Jadi, Allah sungguh-sunguh mengajak orang percaya bersukacita dimana sukacita itu adalah penyataan Allah sendiri dan yang telah mengerjakannya bagi orang percaya.

Mengapa orang percaya harus bergembira? Dalam bahasa Yunani avgalliw,menoi - agalliomenoiditerjemahkan sangat bergembira, bersorak. ${ }^{86}$ Kistemaker memberi komentar demikian "Why are Christians overjoyed? Once again Peter directs our attention to the imminent coming of Jesus Christ (1 Cor. 1:7). At the return of Christ, the believer will see the glory and splendor of the coming age in its fullness (refer to Matt. 25:31). Christ is the victor and all his followers share in His victory. Together they participate in Christ's glory (Rom. 8:17). Therefore, when we contemplate the glory we shall inherit with Christ, we are unable to refrain from: axulting, jubilating, skipping and bubling over with shout of delight., 87

83 Henk ten Napel, Etika Perjanjian Baru: Jalan Yang Lebih Utama Lagi (Jakarta: BPK Gunung Mulia, 1991), 174-175.

84 Geoffrey W. Bromiley, Theological Dictionary..., 178- 180.

85 J. D. Douglas, Ensiklopedi Alkitab..., 98.

86 Hasan Sutanto, Perjanjian Baru Interlinier..., 4.

87 Simon J. Kistemaker, New Testament Commentary..., 175. 
Penderitaan yang dialami oleh orang percaya berarti ikut berpartisipasi dalam penderitaan dan kemuliaan Kristus. Pada kedatangan Kristus, orang percaya akan melihat kemuliaan dan kemegahan datang dalam kepenuhannya. Kristus adalah pemenang dan semua pengikut-Nya berbagi dalam kemenangan-Nya. Orang percaya bersama-sama mewarisi kemuliaan kristus, bersukaria, bergembira, melompat dan bersorak dengan kesenangan. Dengan demikian, bahwa orang percaya memiliki alasan yang kuat untuk tetap bergembira sekalipun mengalami penderitaan. Sebagai orang berdukacita, namun senantiasa bersukacita; sebagai orang miskin, namun memperkaya banyak orang; sebagai orang tak bermilik, sekalipun kami memiliki segala sesuatu (2 Kor. 6:10).

\section{Sebab-SebabPenderitaan}

Petrus menyampaikan suatu realita, yaituovneidi,zesqe- oneidizesthe(present, passive indicative) kata dasarovneidi,zw- oneidizo -diartikan dicela, dihina. ${ }^{88}$ Bromiley mengartikan to upbraid, to revile, to bring reproaches or complaints. $^{89}$ Pemakaian modus indikatif berarti secara terus menerus orang percaya dicela, dihina.Penghinaan adalah hal yang paling sering dialami oleh orang Kristen. Penghinaan dengan kata-kata dari orang yang tidak percaya. Hal ini didukung oleh pandangan Kistemaker yang mengatakan demikian: ... Peter ... if you are insulted, he is pointing to actual insulted to which the Christians have to submit. They meet verbal and not physical abuse from unbelievers. ${ }^{90}$ Hinaan dan celaan adalah penderitaan yang sering dihadapi orang percaya karena nama Cristou-Kristou.Khristos berarti Dia yang telah diurapi. Kata Kristus merupakan terjemahan bahasa Yunani untuk kata Mesias di dalam bahasa Ibrani dan Aram. Kristus adalah nama dari Tuhan Yesus, sedangkan Mesias adalah nama kehormatan. ${ }^{91}$ Konsep "Nama Kristus" dalam ayat ini adalah mencakup pelayanan Yesus yaitu: berkhotbah, mengajar, membaptis, berdoa, dan menyembuhkan.Rasul-rasul berbicara dalam nama Yesus dan memberitakan firman dan Yesus memberikan kuasa dan otoritas kepada mereka (Kis. 4:7-12). Jadi, Kristus membawa kabar baik dan mengajarkan kebenaran bagi dunia dengan kuasa dan otoritas, dan membuat suatu pembaharuan bagi dunia yang telah jatuh dalam dosa. Tetapi dunia menolaknya, menolak orang percaya dan menganiaya mereka tanpa belas kasihan. Mereka dianiaya tanpa belas kasihan, karena orang-orang percaya memberitakan nama Yesus di antara orang Yahudi dan Romawi.

Rasul Petrus menulis dua kali you are blessed atau beatitude. Pemakaian beatitude keduanya dalam konteks penderitaan (1 Ptr. 3:14; 4:14).

88 Hasan Sutanto, Perjanjian Baru Interlinier..., 572.

89 Geoffrey W. Bromiley, Theological Dictionary..., 693.

90 Simon J. Kistemaker, New Testament Commentary..., 175.

91 Hasan Sutanto, Perjanjian Baru Interlinier..., 818. 
Tetapi dalam bagian kedua merupakan suatu kalimat bersyarat. Bromiley menjelaskan kata makarios dalam bentuk kata kerja makarizo artinya dipuji sebagai, atau diberkati sebagai suatu keadaan atau kondisi dimana dia dipuji, diagungkan dan kata ini pertama kali digunakan oleh Aristoteles untuk mengungkapkan kata beatitude atau kebahagiaan yang melimpah. ${ }^{92}$

Dengan kata lain, walaupun orang percaya dicela dan dihina karena nama Kristus, namun mereka adalah orang yang berbahagia, orang yang diberkati. Orang percaya yang dicela atau dihina karena nama Kristus mereka memiliki kebahagiaan yang melimpahsebab Roh Kemuliaan, yaitu Roh Allah ada padamu. Orang percaya yang menderita dapat mengalami kemuliaan-Nya melalui Roh Kudus. Orang-orang yang mati syahid dapat menaikkan pujian kepada Allah sementara berada di tengah api pencobaan yang ganas, dianiaya, dipenjarakan dan mati tanpa mengeluh atau mengadakan perlawanan terhadap orang-orang yang menangkap mereka.

Pemakaianmh. ga,r tij u`mw/n- me gar tis humen - artinya jangan ada orang. Kalimat ini mengindikasikan, rupanya ada orang yang telah dihukum karena telah melakukan kejahatan, sehingga Petrus menasihatkan kepada orang percaya jangan ada dari kamu harus menanggung hukuman karena kejahatan.Hal ini dapat dilihat dari katapasce,tw- paskheto -(present, active)artinya mengalami, menderita, mengalami kematian. ${ }^{93}$ Dapat juga diterjemahkan seseorang yang selalu mendapat hukuman atau mengalami penderitaan karena selalu melakukan kejahatan. Beberapa jenis kejahatan yang disebutkan dalam bagian ini yaitu:

Pertama, foneu.j- phoneus, dalam NIV murdererartinya pembunuh.Kedua, kle,pthj- kleptes-dalam NIV memakai kata thiefartinya pencuri. Ketiga, kakopoio.j- kakopoios-dalam NIV memakai kata criminalartinya yang berbuat jahat. Keempat, avllotriepi,skopojallotriepiskopos-dalam NIV memakai kata meddlerartinya orang yang suka mencampuri urusan orang lain. ${ }^{94}$

Keempat jenis kejahatan yang tersebut di atas memakai tense yang sama yaitu noun, masculin, singular, nominative. Nominative menunjuk kepada pelaku atau orang yang melakukan kejahatan.Tanpa ditafsirkan secara panjang lebar, keempat jenis kejahatan yang tersebut di atas tentu dapat dimengerti maksudnya. Keempatnya adalah jenis kejahatan dalam bentuk fisik. Hal ini mengindikasikan bahwa tidak semua penderitaan adalah "api siksaan."

Wiersbe memberikan komentar demikian jika seorang percaya yang terkenal melanggar hukum dan jatuh dalam kesukaran hukuman, atau menjadi seorang yang suka mencampuri urusan orang lain, memang ia pantas menderita! Fakta bahwa kita menjadi Kristen bukanlah suatu jaminan untuk

92 Geoffrey W. Bromiley, Theological Dictionary..., 548.

93 Hasan Sutanto, Perjanjian Baru Interlinier ...,618.

94 Ibid 
terlepas dari konsekwensi yang wajar atas kelakuan kita yang salah. Kita mungkin tidak melakukan kesalahan dengan membunuh orang (sekalipun marah dapat disamakan dengan pembunuhan di dalam hati, Mat. 5:21-26), tetapi bagaimana dengan mencuri, atau mencampuri urusan orang lain? Ketika Abraham, Daud, Petrus dan "tokoh-tokoh" Alkitab yang lain yang tidak taat kepada Allah, mereka menderita karenanya: sebab itu, siapakah kita maka kita dapat bebas dari penderitaan?" 95

Dengan demikian dapat disimpulkan bahwa sekalipun seseorang sudah percaya kepada Tuhan, jika melakukan kejahatan, tidaklah luput dari hukuman. Oleh karena itu, Petrus menasehatkan agar semua orang percaya menjaga jangan lagi ada yang menderita karena melakukan kejahatan, melainkan karena kita orang percaya.

\section{Sikap Etis Kristen Terhadap Penderitaan}

Pernyataan, mh.aivscune,sqw- me aiskhunestho - dapat diterjemahkan janganlah malu mengakui status sebagai orang percaya yang juga harus ditunjukkan dalam perbuatan nyata tiap-tiap hari. Sebagai orang percaya tidak boleh malu mengakui status sebagai orang percaya sekalipun istilah "orang Kristen"96 sering dianggap sebagai suatu sindiran bahkan sampai diperhadapkan dengan tantangan ataupun penderitaan.

Herodes Agripa yang licik itu memakainya (Kis. 26:28), pasti untuk menyindir Paulus (Mattingley menerjemahkannya, "Segera kamu akan menggerakkan aku untuk mendaftarkan diri Christianus'). Petrus, mungkin dari Roma, sebelum penghambatan oleh Nero, mengingatkan 'para orangorang pilihan' di bagian Asia Kecil, supaya seorangpun jangan malu jika dipanggil untuk menderita sebagai Kristen (1 Ptr. 4:16 - ini tidak perlu mengandung di dalamnya suatu tuduhan formal dalam peradilan). Menurut Tacius (Ann. 15.44) Nero melancarkan tuduhan-tuduhan palsu terhadap suatu mazhab yang masyarakat umum sedangmenyebutya' orang Kristen'. 97

Orang percaya tidak boleh membiarkan setan membuatnya malu dengan penderitaannya. Setan akan berusaha mengecilkan hati dan mematahkan harapan orang yang menderita. Jika orang percaya menyadari bahwa penderitaan bagi Yesus bukan sesuatu yang luar biasa dan orang Kristen di seluruh dunia sedang menghadapi situasi yang sama, ia akan terbangkitkan. Petrus berkata: "Tetapi, jika ia menderita sebagai orang Kristen,

95 Warren W. Wiersbe, Pengharapan..., 129.

96 Sebutan ini muncul tiga kali (Kis. 11:26; 26:28; 1 Ptr. 4:16). Ketiganya mengandung gagasan bahwa Kristen adalah gelar yang diakui umum pada zaman PB, sekalipun jelas ada sebutan-sebutan lain yang dipakai oleh orang Kristen sendiri, yang barangkali lebih disukai. J. D. Douglas, Ensiklopedi Alkitab..., 593.

97 J. D. Douglas, Ensiklopedi Alkitab..., 594. 
maka janganlah ia malu, melainkan hendaklah ia memuliakan Allah dalam nama Kristus itu" (1 Ptr. 4:16).

doxaze,tw de to.n qeo.n- doxazeto de ton theon- dapat diartikan memuliakan Allah, hanya ditujukan kepada Allah.Perkataan "jangan malu" adalah negatif, sedangkan "memuliakan Allah" adalah positif. Supaya kita menjadi saksi yang seimbang, kita perlu mengalami hal itu. Jika kita berusaha untuk memuliakan Allah, maka kita tidak akan malu terhadap nama Kristus. Ketetapan hati untuk tidak merasa malu inilah yang mendorong Paulus ketika ia pergi ke Roma (Rm. 1:16), ketika ia menderita di Roma (Flp. 1:20-21), dan ketika ia mati syahid di Roma (2 Tim. 1:12). ${ }^{98}$

Michaels memberikan komentar demikian doxaze,tw de to.n qeo.n, "only glorify God."Peter wants to make sure ...that he wants them to acknowledge their faith in Christ openly and without fear, regardless of the consequences. As in the case of their ministry to one another, glorification of God depends on attitudes and behavior toward other people. ${ }^{99}$

Dengan demikian ada harga yang harus dibayar oleh orang percaya. Dalam hal ini, sikap terbuka sangat penting. Orang percaya hendaknya membuka hati dan tidak perlu malu dan takut terhadap penderitaan karena nama Kristus.

\section{KESIMPULAN}

Semua orang percaya harus memahami dan meyakini bahwa Allah adalah sumber kasih. Adalah penting memiliki pemahaman yang benar tentang Allah dan kasih-Nya supaya orang percaya tidak salah mengerti bahwa kasih Allah tidak selalu diartikan dengan sesuatu yang menyenangkan atau membahagiakan sebagaimana konsep manusia pada umumnya. Pemahaman yang benar akan Allah harus diwujudkan dengan sikap hidup yang benar. Sehingga dalam segala keadaan, baik bahagia maupun menderita, tetap memuji Tuhan. Kemampuan dan kekuatan orang percaya dalam menghadapi penderitaan dan api siksaan akan membuat kasih Allah semakin tampak nyata.

Hal yang tidak kalah penting adalah sikap rendah hati dan ketetapan hati. Sikap rendah hati akanmemampukan orang percaya mengambil bagian dalam penderitaan Kristus, tidak bersungut-sungut, mengeluh, dan menyalahkan Tuhan saat penderitaan melanda tetapi disanggupkan untuk bersukacita. Dan ketika orang percaya menghadapi kebencian dunia yang membenci kebenaran, perlu memiliki ketetapan hati untuk memuliakan Allah dengan menyatakan kebenaran maka kita tidak akan merasa malu, justru akan mendorong kita untuk terus taat kepada panggilan-Nya yang unik itu.

98 Warren W. Wiersbe, Pengharapan..., 130.

99 J. Ramsey Michaels, Word Biblical..., 269. 
Missio Ecclesiae, 8(1), April 2019, 58-80

\section{DAFTAR PUSTAKA}

2003 Pusat Bahasa Departemen Pendidikan Nasional, Kamus Besar Bahasa Indonesia Edisi 3, Jakarta: Balai Pustaka

1983 Pusat Pembinaan Dan Pengembangan Bahasa Departemen Pendidikan Dan Kebudayaan, Kamus Bahasa Indonesia I (Jakarta: Departemen Pendidikan Dan Kebudayaan

Andy \& Rina

2009 (ed.), Batu-Batu Tersembunyi Dalam Pondasi Kita, Kisah Para Martir Sepanjang Abad, Surabaya: KDP

Charles F. Pfeiffer \& Everett F Harrison,

2001 The Wycliffe Bible Commentary, Malang: Gandum Mas.

Donald Guthrie,

2009 Pengantar Perjanjian Baru Volume 3, Surabaya: Momentum.

Drewes,B. F.

2006 Kunci Bahasa Yunani Perjanjian Baru Surat Roma Hingga Kitab Wahyu, Jakarta: BPK Gunung Mulia.

Edwin A. Blum,

1981 The Expositor's Bible Commentary Vol. 12, Hebrews Revelation, Grand Rapids, Michigan: Zondervan Publishing House

Everett F. Harrison

1975 (ed.), Baker's Dictionary of Theology (Grand Rapids, Michigan: Baker Book House

Francis Brown,

1978 Hebrew And English Lexicon (Lafayette, Indiana: Assosiated Publishers And Autors, Inc.,

Geoffrey W. Bromiley,

1986 Theological Dictionary of The New Testament, Grand Rapids, Michigan: William B. Eerdmans Publishing Company. 
Hasan Sutanto,

2006 Perjanjian Baru Interlinier Konkordansi Jilid II, Jakarta: LAI

Henk ten Napel

1991 Etika Perjanjian Baru: Jalan Yang Lebih Utama Lagi , Jakarta: BPK Gunung Mulia

J. Ramsey Michaels,

1988 Word Biblical Commentary 1 Peter, Waco, Texas: Word Books Publisher.

John Joseph Owen,

1994 Analitycal Key to The Old Testament Vol. 4 (Isaiah-Malachi) Grand Rapids, Michigan: Baker Book House.

K. Riedel,

1952 Kamus Istilah Teologia (Jakarta: Badan Penerbit Kristen

Lie, Bedjo

2011 "Penderitaan Menurut Agama Buddha: Sebuah Tinjauan Kritis Dari Perspektif Kristen" (Artikel),

Merril C. Tenney,

2006 Survey Perjanjian Baru, Malang: Gandum Mas.

Ola Tulluan,

1999 Introduksi Perjanjian Baru Batu: Departemen Literatur YPPII.

Purba, B. Kreysen

2010 "Menderita Karena Pilihan: Sebuah Renungan Tentang Imperatif Penderitaan Di Tengah Komunitas Yang Pluralistik", Jurnal Teologi Stulos, Bandung: STTB

2010 Suffering" The American Heritage Dictionary of The English Language, ed. Ke-4, Houghton Mifflin Company, 2009; Stulos Jurnal Teologi, Bandung: STTB,

R. Laird Harris,

1980 Theological Wordbook of The Old Testament Vol. 1 Chicago:

Moody Press 
Salim, Peter

2006 The Contemparary English-Indonesia Dictionary Volume 2 (Jakarta: Media Eka Pustaka

Simon \& Christoper Denes,

2000 Masalah-Masalah Moral Sosial Aktual Dalam Perspektif Iman

Kristen Yogyakarta: Kanisius

.Simon J. Kistemaker,

1987 New Testament Commentary Peter and Jude, Grand Rapids, Michigan: Baker Book House.

Sinclair B. Ferguson \& David F. Wright 2009 (ed.), New Dictionary of Theology Jilid 2, Malang: SAAT.

Takaliuang, Erni

2008 Eksposisi Injil Matius (Diktat Kuliah), Batu: Institut Injil Indonesia.

W. R. F. Browning,

2008 Kamus Alkitab, Jakarta: BPK Gunung Mulia

Warren W. Wiersbe,

1982 Pengharapan Di Dalam Kristus (Bandung: Kalam Hidup.

\section{Sumber Internet:}

Aulia Bintang Pratama, "Pembakaran Gereja Capai 1.000 Kasus Pasca Reformasi" dalam CNN Nasional, https://m.cnnindonesia.com, (akses, Rabu, 10 Oktober 2015)

http://perawattegal.wordpress.com/2009/08/31/konsep-sehat-sakit/, 31 Agustus 2008, 1.30am.

http://youmy88.blogspot.com/2011/03/manusia-dan-penderitaan.html.

http://mantapblogs.blogspot.com

http://id.wikipedia.org/wiki/siksaan, 25 Juli 2011, 3.37PM.

http://pesta.org/prk_pel06, 20 Juli 2011, 1.11am.

www.gkri-exodus.org, 16 Juni 2011, 4.26PM 